\title{
Gender Access Gap In Basic Education: Can Non-Governmental Organizations (NGOs) Provide A Panacea In The Northern Region Of Ghana?
}

\author{
Eliasu Alhassan ${ }^{1, *} \&$ Iddrisu Sulemana ${ }^{2}$ \\ ${ }^{1}$ University for Development Studies, Ghana \\ ${ }^{2}$ Tamale Polytechnic, Ghana \\ *Corresponding author: University for Development Studies, Ghana. E-mail: \\ eliasua@yahoo.com/aeliasu@uds.edu.gh
}

Received: July 8, 2014 Accepted: August 12, 2014 Published: September 23, 2014

doi:10.5296/ije.v6i3.6346ＵRL: http://dx.doi.org/10.5296/ije.v6i3.6346

\begin{abstract}
Fundamentally, the question is no longer whether NGOs should play a role in education in Northern Region but how they are most likely to improve quality and access to basic education. This paper examines comprehensively whether NGOs in Northern Region have been able to provide a solution to the gender access gap in enrolment and attendance, the kind of relationship they have with GES and their challenges. The study was both qualitative and descriptive. Instruments such as interview guide observation and semi- structured interview schedule were used to source the primary data from the selected NGO officials, the District Directors, the pupils' and the headteachers while the secondary data were sourced from journals internet and published thesis. The study revealed that The activities undertaken by NGOs to address gender access gap in the region include research on girls' education, advocacy by using media to educate the public on the need for girls' education, capacity building, especially training of teachers and school girls, provision of both teacher and girls incentives, formation of girls clubs and training of parents to be able to cope with their girls' education. The study also showed that non-availability of data at the District Education Offices, Lack of cooperation on the part of District Education Officials and lack of Logistics at the District Offices make it very difficult to provide a solution to the access gap in basic education by NGOs therefore, boys are still ahead of the boys in terms of educational achievement at the basic education level in the Northern Region of Ghana. The paper calls for attitudinal change of both the GES and the NGOs assisting in basic education in the region.
\end{abstract}

Keywords: Basic education, Gender gap, Gender disparity, Enrolment, Attendance 


\section{Introduction}

During the last decade, Non-Governmental Organizations (NGOs) have been increasingly tapped to implement development programs in Ghana. A UNESCO (2011) report explained that in recent years, growing amounts of development resources have been channeled to and through NGOs to assist in education especially in basic education. Also, according to the report (2011), most of the NGOs work to alleviate poverty, improve social welfare and develop civil society. As a result, the NGOs have become more dependent on international donors leading to an explosive growth in local NGOs in many countries including Ghana. This trend can also be found in the education sector especially in basic education sector where most major donor agencies have increased the resources allocated through NGOs to improve access to basic education. More and more, a UNICEF (2012) report noted that donors use international and local NGOs for education service-delivery in both formal and non-formal sectors. Most countries in Africa including Ghana with a donor supported program for the education sector have NGOs playing a significant role in basic education.

NGOs in Ghana have not limited their education activities to service-delivery. They are also involved in lobbying and advocating for educational reforms, working individually and through networks to participate in policy dialogue in many African countries including Ghana. In the context of decentralization in Ghana, NGOs are creating new spaces for civil society involvement in education (UNO 2011). Recent Education for All (EFA) meetings in Johannesburg and Dakar in 2013 recognized the vital role NGOs play in promoting universal and equitable quality of basic education. The EFA discussions have heralded NGOs' new roles as alternative education providers, innovators and advocates policy dialogue partners and donors have begun to engage in technical and institutional capacity-building programs for local NGOs.

A myriad of justifications and assumptions can be found throughout the development literature as to why NGOs in Ghana should play a growing role in the education sector, many that mirror the argument to increase the role of NGOs more in the basic sector of education. NGOs work at the community-level thus affecting social change where others cannot. NGOs can represent and catalyze civil society, an element many consider critical for sustainability and democratization.

Trying to discern whether NGO interventions in the basic education sector have lived up to expectations is a complex task and is more theoretical than practical. This paper responds to a more modest but ultimately more useful concern especially whether NGOs have been able to close the gender access gap in basic education in the Northern Region. It presents a comprehensive portrayal of how NGOs have in fact intervened in the basic education sector, how their presence and relationships with government (Ghana Education Service) affect gender access gap in basic education and which contextual challenges have NGOs' face in their intervention and collaborations with the Ghana Education Service.

Capability Approach and Social Justice in Education theories by Sen (2007) which the paper heavily relied on stresses the need to involve all partners or stakeholders assisting in education in designing programmes and activities. These stakeholders include the NGOs, the 
pupils, parents and teachers in order to ensure social justice and parity in basic education. The lessons learned from this study are meant to inform those involved in educational development: Ghana Education Service Ministries of Education and NGOs why after many decades of NGOs presence in the region gender access gap still exist in the Northern Region of Ghana?

\section{Research Methods and Profile of selected NGOs}

The target population of the study comprised NGOs, the Ghana Education Service officials, head teachers as well as the school pupils. The sample size was 73. Ten districts were selected through simple random sampling. Twumasi (2001) noted that when simple random sampling technique is used all the respondents have equal chance of being selected. Ten (10) district Directors were contacted and interviewed. The districts were:

Table 1. Selected Districts and Metropolitan Areas and their Populations

\begin{tabular}{llll}
\hline Districts & Male Population & Female Population & Total \\
\hline East .Mamprusi & 59,453 & 61,556 & 121,009 \\
Tolon Kumbungu & 56,046 & 56,285 & 112,331 \\
West Mamprusi & 83,005 & 83,006 & 168,011 \\
Savelugu Nanton & 67,531 & 71,752 & 139,283 \\
Tamale & 185,995 & 185,356 & 371,351 \\
Gushegu /.Karaga & 91,522 & 97,443 & 188,965 \\
Zabzugu Tatale & 61,085 & 62,769 & 123,854 \\
Saboba/.Chereponi & 58,526 & 60,574 & 119,100 \\
East Gonja & 69,721 & 65,729 & 135,450 \\
Bole & 31,022 & 30,571 & 61,593 \\
\hline
\end{tabular}

Source: Ghana Statistical Service (2012)

Thirty (30) headteachers 30 pupils (15 girls and 15 boys) and education sector programme directors of 3 NGOs were all interviewed. The NGOs were Campaign for Female Education (CAMFED) Send Foundation and Action aid Ghana. These were NGOs which were operating simultaneously in all the selected 10 districts of the Northern Region. With regard to the sampling technique, purposive sampling was used to select the respondents. The study was done in the Northern Region of Ghana with instruments such as interview guides and questionnaire hence, in-depth interviews were done with different interview guides to source information from the NGOs, District Directors of basic schools in the region while questionnaires were used to source information from the head teachers and the pupils. The data were organised into themes and analysed and in some cases, quotations and descriptive statistics were used to describe and support the information from the field. Secondary data related to the study were obtained from the offices of the selected NGOs, offices of the Ghana Education Service, Journals monographs and the internet. The field work was conducted between January and March 2012. 


\section{Profile of the Selected NGOs}

The Campaign for Female Education is an international non-governmental and non- profit organization dedicated to eradicating poverty in Africa through the education of girls and empowerment of young women. The NGO operates in Zimbabwe, Zambia, Ghana, Tanzania and Malawi. It was founded by Ann Cotton after being inspired by her travel to Zimbabwe in 1992. In 1993, Ann started CAMFED by fund raising and the first 32 girls were supported into school in two of the most impoverished districts of Zimbabwe.

CAMFED Association, popularly known as “Cama,” was established in 1998 to connect young female school leavers and offer them post-secondary school training opportunities in managing money. Cama provides a structure through which its members can develop their activism and leadership. The NGO has its headquarters and a registered charity in the UK which was established in 1993. In Ghana the NGO was established in 2002 and the focus is on rural areas where poverty is widespread and girls and young women face exclusion from education and opportunities that are offered by education. CAMFED works to build around girls a supportive environment in which they can attend and succeed at primary and secondary school levels and progress into young adulthood with opportunities that include professional training, higher education and job creation. By the end of 2010, CAMFED had provided: 1,451,600 children in some of the poorest communities in rural Northern Ghana with access to a safer, improved school environment (www.camfedghana.com).

SEND Foundation is a Non-Governmental Organization (NGO) established in August 1998 with the maiden name of Social Enterprise Development Foundation. The NGO started the implementation of its first programme of the Eastern Corridor Livelihood Security Promotion Program (ECLSPP), aimed at addressing the practical needs of communities through an integrated approach to service delivery. The Social Enterprise Development Foundation Ghana has marked fourteen years of empowering individuals with skills to hold public office holders accountable as well as projecting the rights of the disabled, women and ordinary citizens.

Established on the $8^{\text {th }}$ of August 1998, SEND Ghana revolutionized pro-poor policy advocacy thereby contributing to creating the enabling environment for citizens-government engagement and building capacity of different categories of poor people to claim their development rights. The Social Enterprise Development Foundation has three branches across West Africa; SEND Ghana, SEND Liberia and SEND Sierra Leone. Some of the overriding successes of SEND Ghana are the projection and recognition of Persons with Disability (PWD's) in policy document and programme implementation.

The increased participation of small scale food crop farmers in policy making and the identification and recognition of gender equity in basic education as a development challenge in Ghana especially in the Northern Region and the confidence of rural girls and young women and other marginalized groups to participate in policy discussion and demand transparency, equity and accountability in the use of public financial resources. Being the oldest of such organizations in the sub-region SEND is credited with the introduction of innovative Participatory Monitoring and Evaluation (PM\&E) framework which has been successful in promoting girls participation in basic education in the Northern Region. 
According to Wood and Swan (2001), the NGO's Livelihood promotion programme empowers the poor to attain sustainable livelihood security through farmer co-operatives, credit unions and market access, while Financial NGO delivers micro-finance schemes in the Northern Region. The Eastern Corridor programme promotes livelihood security for the poor and marginalized in conflict-ridden districts in the Northern Region. The programme creates independent community-based farmer co-operatives capable of advocating and addressing the livelihood needs of their families. SEND Ghana mainstreams gender in education and is currently the only NGO in Ghana with gender policy not just for beneficiaries, but for management practices of the organization since 2006 (www.sendghana.com).

Action Aid was founded in 1972 in the UK by a businessman called Cecil Jackson-Cole as a child sponsorship charity that helped communities. It was originally called Action in Distress. During the first decade, the NGO established long-term programmes in India, Rwanda, Kenya, Burundi and the Gambia and responded to emergencies in Honduras and Bangladesh. The focus of the organization is on education, health, sanitation and agricultural projects to improve living conditions for children and their families. The NGO started in Ghana in 1990 with one million people living in 279 communities in Upper East, Upper West, Northern Region, Brong-Ahafo, Volta Region and Greater Accra Region. The NGO's vision for education extends to working with the government to form partnerships across society to ensure quality early childhood education and adult learning that is linked to social change (www.actionaidghana.com).

The organization aims at increasing citizens' participation in farming and managing education policy, promote access to basic education as a right, support efforts for sufficient resources to the education sector and support efforts to increase access to basic education and retention of girls in school and secure their rights. By the mid-eighties Action Aid was reaching over 40,000 children in Asia and Africa, and expanded further by setting up affiliates in Ireland, Italy, France and Spain. The NGO began to shift its focus towards tackling the root causes of poverty and gender disparity in education. The organization began to work with communities to boost agricultural production, improve water supplies, gain access to basic education, healthcare and find new ways of making a better living. The NGO helped poor people organize themselves to challenge injustice and demand their rights from their own governments. By 1990 Action Aid was working in over 30 countries, helping people get good healthcare and basic education (Action Aid Ghana 2012). In the mid-1990s, after pilot projects in Bangladesh, El Salvador and Uganda, Action Aid launched Reflect, a pioneering adult literacy tool. Its success rate means it is now used by over 500 organizations in over 70 countries. In 1998 the organization expanded its work to include peace building and conflict resolution in Africa and lobbying financial institution such as the World Trade Organization in 1990 (actionaidghana.com).

In 2003 Action Aid International headquarters was launched in South Africa and working towards giving all our country programmes an equal say in how the organization works, the new structure makes real the organization's commitment to accountability to the people, communities and countries. The organization work just to make it more effective in fighting and eradicating poverty and by the end of the decade, the NGO has helped over 25 million 
people in over 40 countries in the world with their own fight against poverty and increasing access to basic education (actionaidghana.com accessed).

\section{Major Findings}

\subsection{Areas of NGOs Intervention}

The study found that NGOs in the Northern Region intervene in the area of research on girls' enrolment, attendance, performance and dropout in basic schools in the Northern Region. It was observed that outside the operational records of the NGOs, documentation on girls' education, especially in enrolment and attendance in the region have not been systematically consolidated and therefore very difficult to get information relevant to gender disparity in girls enrolment and attendance. This makes the NGOs intervention to bridge the gender access gap unsuccessful in the Northern Region of Ghana. The Programme Director of SEND Foundation in charge of Girls' Education confirmed the findings in an exclusive interview, he said:

"Intervening in research relevant to enrolment and attendance at the basic level has never been easy. Data on enrolment and attendance are rarely documented at both the regional and national levels. At times, when information on researched work already undertaken is needed, such information cannot be found at the Regional Education Office not to talk about the national offices. This makes it very difficult to make comparison between girls and boys so far as disparity in school enrolment and attendance are concerned in the basic schools"

On the part of the District Directors of Education, they explained that they have good relationship with the NGOs operating in their districts, especially NGOs which partner in girls education but confessed that the documentation of collaborated research findings are always a problem, especially in enrolment and attendance. The Statistical Unit within the offices sometimes use manual documentation which makes a lot of the document to mix up with other documents which the NGOs find difficult to trace when the need arises. In his opinion he believed that the NGOs inability to find a solution to the gender access in enrolment and attendance. One of the District Directors of Education did not agree that the loss of the collaborated research work on enrolment and attendance should be attributed to them and explained that the collaborated research findings are always forwarded to the regional education office for validation before it comes back for documentation, at times, the data is sent there and in the process of validation get lost in the system.

It can be interpreted from the above that the NGOs intervene in the form of collaboration with GES in research on girls' enrolment and attendance there was therefore no evidence in the form of a document containing collaborated research work from either the NGOs or the GES to ascertain the efficacy on gender disparity in education. Therefore disparity still persists in enrolment in favour of the girls while disparity in attendance favours the boys. This is one of the reasons why the NGOs operated in the region for decades and are unable to find a solution to the gender access gap in enrolment and attendance in basic schools in the 
region. The relationship between the NGOs and the GES is not as cordial as expected.

In a response to a question relating to the relationship between the NGOs and the GES, the headteachers had a different view they described the relationship as very cordial. Sixty seven percent (67 percent) of the headteachers said that the relationship between the Ghana Education Service and the NGOs is very cordial; twenty (20) percent of them said it is cordial while thirteen percent (13) of them said the relationship is not cordial. Those who said the relationship is very cordial explained that before an NGO steps on the school premises, the headteachers will be informed first by the District Director of Education and advise them to try as much as possible to cooperate with the NGO in question. This means that the districts are often aware of all NGOs assisting in girls' education in their various districts. As one of the headteachers remarked:

"We have enjoyed a lot from the NGOs assisting our school girls. They provide our girls with books, pens and pencils and sometimes textbooks and this motivates our girls to attend school, work hard so that they can catch up with the boys”.

The headteachers who said the relationship is cordial explained that at times the District Directors of Education only informed them about an NGO after the NGO has ended its programme on the girl child. Sometimes the District Directors of Education do not even inform them unless they go to the District Office to find out whether the directors are aware of the presence of a particular NGO and the response is always affirmative. The thirteen (13 percent) had a different view as far as the collaboration was concerned. According to the headteachers, the NGOs deal directly with the District Education Office without involving the school and this does not augur well for the school and the NGOs for effective collaboration. The NGOs on their part explained that the Ghana Education Service cooperates with them but the District Directors of Education sometimes delay the approval process when it comes to the implementation stage. During the interviews with the District Directors of Education, they explained that their relationship with the NGOs is very cordial but added that some of the NGO programmes need to be approved by the Regional Director of Education, which sometimes delay the process but efforts are being made to eliminate these delays so that the NGOs can implement their programmes successfully.

As to whether the collaboration in research has seen more positive effects on girls' access in term of enrolment and attendance, it was observed that there was no data at the GES offices at the district levels to confirm the positive effects on enrolment and attendance. The researcher could not also trace any from the NGOs or from the headteachers. When the headteachers were asked, they explained that they always forward such data to the District Directors Office on request, sometimes, when they need the data for references they do not get it back and this also accounts for the inability of the NGOs to find a panacea to gender access gap which have bedeviled the region for decades. One of the heads said:

"We normally experience high enrolment figures and high attendance on the part of the girls, but we have never sustained the figures because it keeps on dwindling. We cannot also trace the data for references". 
It can be said that majority of the District Education Directors do not collaborate well with the NGOs, there are many challenges relevant to data documentation and validation. Data on enrolment, attendance and dropout were not sustainable, research on enrolment and attendance did not close the gender disparity gap therefore, gender disparity in enrolment and attendance still favour the boys in many cases in the region, especially in schools where the School Feeding Programme does not operate.

It was again observed that advocacy in various forms constituted a strong area of activity in the NGOs intervention in the Northern Region. These activities are engaged at different levels within the operation areas of the NGOs and it affected positively on girls' enrolment and attendance in basic schools in the Northern Region of Ghana. This was not enough to completely solve the gender access gap hence the gap still exists either in favour of the boys or the girls. The District Directors supported this finding during the interview. They explained that advocacy continues to be an important requirement; it permeates the social fabric in response to the vast need for attitudinal change in the community. Parents in most of the districts now see the need to enrol the girl child in school and allow her to attend. The Director in Charge of Education Programme of Send Foundation Ghana also supported the observation made by the author, he said:

"As part of our programme of activities, we play advocacy for the facilitation of girls education in the region with members of the District Assembly and traditional rulers, especially on the negative effects of customs and traditions on girls education we do this in order to achieve change in traditional models of thought and adaptation of customs, public education on the need to send the girl child to school at the national and local level through community meetings, workshops and radio and television".

The NGOs further explained that they advocate for promotion and sustain awareness about the importance of girl child education in some selected districts especially, districts where the participation of girl child in education is very low. It was further observed that the NGOS initiate programs at the district levels and dissemination of workshops for sensitization of parents, chiefs, teachers and girls on the relevance of girls' education in order to eliminate the socio cultural and economic barriers to girls' education and this has yielded positive results in enrolment of children, especially the girl child which has bridged the gender disparity gap in enrolment and attendance in basic schools in the Northern Region to some extent. The headteachers explained that the NGOs are doing their best to remove many barriers to girls education in their schools but the support they receive from the District Directors of Education has not been the best because some of them explained that they have never seen any member of Ghana Education Service in their schools to monitor the activities concerning advocacy, also the District Director have never asked them what their schools have achieved as a result of the NGOs activities.

As to whether the advocacy by the NGOs has addressed the gender access gap in their schools, it was found that disparity continues to persist in favour of the boy child in 
attendance, enrolment of girls and attendance are not always sustainable. It can be said that though the NGOs are doing their best in the area of advocacy in the region by training teachers on effective teaching methodology, education of parents on how to promote, sustain and creation of awareness on the plight of the girl child through workshops, it does not reflect on the purpose for which the advocacy is being carried out, gender disparity in the basic schools in the region still exist in favour of the boys, especially in school attendance.

There were various types of scholarship schemes for girls of various types and at various levels and these scholarship schemes were highly pervasive in the intervention. Most of the NGOs award incentives and scholarships to girls in order to motivate them to stay in school and attend school regularly as well as perform well in class. These scholarships which are much realized at the basic level have positive effects on girls' enrolment and attendance. It is these incentives that really make parents to enrol their girls and allow them to stay in school until they attain basic school certification. The NGOs provide incentives such as school uniforms, bicycles both at the Primary and Junior High levels in the districts.

The Programme Director of Campaign for Female Education (CAMFED) confirmed the findings by explaining that these incentives for girls are meant to close the disparity gap between the boys and girls which persisted for decades. The study found that the CAMFEDan NGO operating in the region established scholarship schemes for needy girls since 2008. This involves giving awards and other incentives to girls. It also included payment of school fees at the Senior High Level. During the interview, it was revealed that currently the Campaign for Female Education is supporting a total number of 16,000 females across four regions (Northern, Upper East, Upper West and Brong Ahafo) with scholarship packages such as school fees, uniform, and foot wear. The question still remains, have these incentives really removed the access gap in terms of enrolment and attendance in the basic schools in the region?

The study again found that CAMFED supplied food items to girls in some deprived schools in the districts as a special award for girls for excellent academic performance and attendance. Action Aid also provides bicycles as incentives to girls who stay about twenty kilometers away from their schools. The Programme Officer of Action Aid confirmed this finding and said;

“We provided a number of bicycles to girls at Chereponi in 2010." This was also confirmed by Kouakou (2011). The District Director, when contacted, corroborated this finding by explaining that the Action Aid Ghana has provided 400 bicycles to girls who commute long distances to their schools in the district and this in a way made a lot of girls to attend school especially those staying far away from their schools. The study again found out that the World Food Programme is located in many districts in the region. As part of incentives to the girl child, grain ration was given to girls who attend school regularly to go home in order to motivate them to attend school, especially those who have made 100 percent attendance in a month and this is a relief to parents in the region.

In relation to incentives provision to schools, Tonah (2011) noted that the activities of NGOs in the region provide some form of relief to some sections of the population, especially 
parents. The author noted that the provision of some infrastructure in some schools has somewhat improved enrolment figures considerably, especially in the West Mamprusi District of the Northern Region of Ghana. It can be interpreted then that the scholarship schemes are relevant to girls' participation in basic education. Enrolment has increased and attendance improved and these were as a result of the scholarships schemes put in place by the NGOs. It was again found that some scholarship package included exercise books for girls, sanitary pads, soap and dry food ration and in a response to a question relating to incentives for girls, 97.4 percent of the girls said they do receive these incentives while 2.6 percent said they do not receive these incentives. It was found that 55 percent of the girls from the primary schools in the Northern Region have progressed to the Junior High School and 45 percent of them have progressed from the JHS to the Senior High School. As to how the Ghana Education Service collaborated with them in this sponsorship, the Director of the SEND foundation explained that the success could not have been possible without the cooperation of the GES, parents and the teachers. All played their respective roles and this is in line with the theory of social justice as explained by Sen (2007). This means that in terms of intervention in the area of scholarships, the Ghana Education Service has given the NGOs the necessary support to carry the scholarship schemes and these positively affected girls' school enrolment and attendance more than the boys.

Action Aid Ghana has helped and sponsored over 300 girls to Senior High School level. This was revealed during the interview with the Programme Director and confirmed by Kouakou (2011). When the author asked the Director the essence of these sponsorships, he explained that disparity between boys and girls in enrolment and attendance in the region is serious that this sponsorship is meant to motivate the upcoming girls to attend school, study hard and pass their examination. As to whether they encounter any problem with the District Directors of Education in the region, the NGO explained that the Directors were committed to the course but added that it was when we needed data on current enrolment and attendance for the evaluation of the programme that they experienced some difficulty with the directors. The Programme Director explained that they need these data to set as bases so that proper evaluation of our achievements can be assessed.

The study established that in an attempt by the NGOs to bridge the gender access gap between boys and girls in enrolment and attendance they go through difficulties with the Ghana Education Service to make their dreams come true and this has added to the inability to address the access gap in the region. Though the NGOs have made important gains in area of incentives and scholarships to girls, there has not been much reflection on girls' enrolment and attendance in the basic schools in the region. The study found that the NGOs in their intervention train Ghana Education Service Officials, especially the girl child education officials on how to manage the Girl Child Education Units, also how to handle the girl child in their various districts in the region. This training was centered on issues of enrolment, attendance and retention of girls in the basic schools.

The Tolon Kumbungu District Education Director in the Northern Region corroborated the finding. He explained that in Tolon Kumbungu and the Zabzugu Districts in 2009, UNICEF provided a number of logistics support for the training of Ghana Education Service officials, 
the School Management Committees and Organization of workshops for the training of teachers on how to handle and motivate the girl child. It also included an orientation for teachers on gender disparity issues and also encourages teachers to improve upon their performance in the classrooms and outside the classrooms.

It was found that the Non-Governmental Organizations, as part of the collaboration with the Ghana Education Service, organized best teacher awards competition for teachers and prizes were awarded to deserving teachers in the Saboba District in 2009. The study further found that in March, 2010 the Girl Child Education Unit within Ghana Education Service organized a two day workshop on the topic: "Communication strategies for promoting gender parity in basic schools in the Northern Region” UNICEF Ghana provided the funding. It can be interpreted that the NGOs collaborate well with the Ghana Education Service in the area of provision of incentives; the assessment of the impact of these incentives was what the NGOs found very difficult to explain since they hardly get the outcomes from Ghana Education Service or get accurate data from the headteachers in the districts. As to whether the headteachers received incentives of any kind from the NGOs assisting girls, 93 percent corroborated what the NGOs earlier said on incentives and scholarships. They said they receive incentives from NGOs which includes: prizes for hard working teachers, scholarship in the form of money for our girls to motivate them to attend school and stay in school, while 6.7 percent said they do not receive incentives from NGOs, what they normally receive come from the District Education Office and they cannot tell whether it is the NGOs that give these incentives via the District Education Office.

As to whether those incentives for girls make any impact on girls' attendance, the responses were affirmative. The headteachers explained that girls now attend school than previously when they were not receiving these incentives. Nonetheless, their attendance cannot be compared with the boys attendance, therefore, the disparity in attendance still exist in favour of the boy-child and this could be attributed to socio-economic and socio-cultural factors which are beyond their control (Alhassan 2010). Abdulai's studies in Mamprusi in (2007) confirmed the current results in the Northern Region when the author explained that raw food ration for only girls in the Mamprusi West in the region as incentive had a positive impact on girls' enrolment. In that case the girls were more enrolled than the boys in schools. It can be said that though the incentives play an important role in girls' attendance but that alone cannot change the disparity situation in the region. The intervention of the NGOs alone cannot resolve the problem of disparity in attendance without the NGOs collaborating effectively with the parents on one hand and the Ghana Education Service on the other hand.

It was found that the Action Aid, CAMFED and SEND Foundation in the Northern Region have all formed girls' clubs in the districts to encourage girls to compete favourably among themselves which in the long run give them confidence to compete with their boy counterparts. The NGOs in an interview attested to this by explaining that the forming of these clubs in the schools had transformation effects on the girls' school attendance and participation in class Also, it made them confident and studious. The NGOs further explained that the objective of these clubs is to improve girls' academic performance via regular school attendance and competition with other clubs, attending workshops relevant to girl child 
education and also to reduce dropout rate as well as close the disparity gap between the boys and girls at the basic school level.

As to whether the NGOs achieved their objectives, the explanation given was that they know they have empowered the girls clubs to function effectively, the achievement of the objectives is supposed to be communicated either verbally or in a written form to the NGOs by the teachers on the ground which the NGOs do not get when the NGOs even go to the school to assess the outcome they do not get the necessary data. It can be interpreted that the achievement of the objectives of the girls' clubs in the basic schools in the region depends largely on the Ghana Education Service, the teachers, the girls and the NGOs. The inability of these stakeholders to manage, sustain and evaluate these clubs defeat the very purpose for which these clubs were set up hence; gender gaps in enrolment and attendance continue to persist, in spite of the formation of girls clubs in the various schools in the region.

\subsection{Challenges of NGOs Intervention and Collaboration}

According to the NGOs, non-availability of data relevant to girls' education at the District Education Office poses a serious threat in their intervention in basic education in the region. The Programme Director of SEND Foundation had this to say in an interview explained that they normally need the existing data of girls' education to use as bases for our intervention so that after the programme implementation, assessment can be done based on the data from Ghana Education Office. The NGOs complained during the interview that they experience what they called inconsistence data at the District Education Offices in the region, a problem which makes them more confused when evaluating their programme on girls' education. They further explained that they found it very difficult to understand why data submitted to the District Offices and on request after some few months, experience errors or inconsistency in the data, either the figures are increased or reduced for the reasons best known to the District Offices. This makes it very difficult for them to trust the Ghana Education Service in their intervention. It is a clear indication that there was lack of trust between the partners involved and this is one of the reasons why the NGOs cannot achieve their targets, especially parity among boys and girls in the region.

It was observed that non availability of research data at some of the District Offices was a common problem of both the NGOs and the Ghana Education Service in the region. The District Director of Saboba Chereponi District during the interview explained that because of lack of experts in data management at the District Offices, most of the data especially, on girls' education get lost in the system. Those handling research findings are not competent enough to preserve the data with the help of the computer. Some districts like Savelugu, Nanton and East Mamprusi had data on enrolment up to 2008 while others have data up to 2005 and some had up to 2006. Only Bole district had data up to 2010. For the NGOs, the study revealed that CAMFED, SEND, and Action Aid had data up to 2010; the data on enrolment before 2008 were inconsistent with the data from the District Offices in the region. The District Directors of Education agreed that data on girls' education, especially issues concerning enrolment and attendance need to be preserved since all the Regional Education Offices throughout the country are working towards the achievement of the targets of the 
Millennium Development Goals in 2015. One of the District Directors of Education said:

"My brother, non-availability of adequate data at the District Offices has actually made the work of the NGOs very difficult. At times; they rely on us for information before implementing their programmes on girls' education at the basic level. At times they go on their own way to conduct research and find their own data and I think this should be encouraged at all the educational levels."

The District Directors of Education further explained that sometimes, they were accused of what they call "Data Manipulation," an accusation they took an exception to. In their view this accusation does not augur well for effective collaboration in the region. It can be said that the above revelationship explains why almost all the schools visited did not have any records relevant to girls' attendance and also non-availability of enough data on enrolment and attendance in the schools reflected in some of the District Offices in the region. The District Directors of Education in the selected Districts again explained that it has come to their notice that the NGOs collaborating with them in girls education do not trust them and this is manifested in the way they handle their programmes on girls education with them. The District Directors in an interview explained that at times, the NGOs feel reluctant to provide us with data on girls' education in the various districts any time they request for the data they refuse completely to assist them with research findings.

It was again found that some of the NGOs like SEND foundation and Action Aid at times refuse to attend meetings organized by the Ghana Education Service and this makes it very difficult to compare figures with the NGOs which sometimes result in disparities in school enrolment and attendance figures in the districts. It was observed that one of the major problems the GES faces when NGOs intervene was lack of funds at the districts to really support the NGOs to carry out their programmes on girls' education. They explained that the funds allocated to the District Directors of Education are inadequate such that they find it very difficult to assist in funding. As the District Director of East Mamprusi confirmed:

"I sometimes feel embarrassed for my inability to contribute to funding some programmes of the NGOs. At times I need to support by providing lunch for participants at a workshop organized by the NGOs but unavailability of funds at the district always makes it very difficult to support in this direction."

As to how the NGOs react to this attitude, the Directors explained that their refusal to inform them how and when their programmes on girls' education will be implemented give them an impression that they are not happy with them. Also, the NGOs attitude towards them when they request for data on girls education shows that they are not happy with them. When the NGOs were asked to react to what the District Directors said they explained that there are some programmes which need co-sponsorship especially advocacy for training Ghana Education Officers, the District Directors of GES often shirk their responsibility. The NGOs added that they do not refuse giving out any information requested by the GES as the District Directors claimed at times; when the information is not available the Directors do not want to 
believe them. They again explained that disparity in enrolment starts right from the first day of school cycle. Most schools right from kindergarten enrol boys more than girls at the start and some more girls than boys at the start and unless this imbalance is corrected the inevitable result is a permanent gender disparity in enrolment in the region.

\subsection{Lack of Cooperation}

It was again found that Ghana Education Service offices in the region do not cooperate effectively with the NGOs assisting in girls' education in the region. The Director in charge of girls' programme of Action Aid confirmed this by explaining that their programmes on girls education takes a lot of time at the Regional Education Office to be approved by the Regional Director of Education before we implement them in the communities, sometimes when the NGOs go to the District Offices to find out the state of their programmes they do not receive the needed attention. The NGOs again explained that they have time for the Ghana Education Service because they know that they partner them in education in the region.

It was again observed in Bole, Gushegu/ Karaga and Tolon/Kumbungu districts that the schools do not cooperate well with the NGOs to their satisfaction. At times, the NGOs find it difficult reaching the girls of these schools. The headteachers in these schools do not allow the girls to leave the school premises for any NGO programme. They always demand confirmation from the District Directors of Education. This frustrates the NGOs and retards their progress as partners in girls' education in the region. When the headteachers were interviewed, they did not deny the assertion by the NGOs they only added that it is not their making sometimes, they do not release their girls to the NGOs for programmes because of the instructions they receive from the District Directors. The District Directors of Education in the interview explained that some of the NGOs in the districts do not follow the school calendar. At times they want to implement their programmes during vacation which they find difficult to agree with because they could not guarantee the safety of the pupils.

The District Directors in the region explained that the major problem they face with the Non-Governmental Organizations assisting in girls' education in the region is inadequate information flow. They said that most of these NGOs do not consult them before implementing their programmes on girls' education. They may be aware of the programme but when it comes to the implementation phase, they are left out. At times the Circuit Supervisors complain to them after their rounds about what they call girls massive absenteeism in their various districts and the reasons are that an NGO has a workshop or training for all girls in the district. The District Directors of Education further explained that due to lack of constant communication with the NGOs, the NGOs think that they do not cooperate effectively them. One of the District Directors said:

"You see gentleman, we like the collaboration with the NGOs in research, but more often, the NGOs do not tell us the time for the implementation of their programmes so that we can prepare for them."

The above assertion by the directors indicates that there is some collaboration but it is not 
effective as both the directors and the NGOs expect. This could be one of the reasons why disparity in basic education still persists in spite of the collaboration between the NGOs and the Ghana Education Service which existed over decades in Northern Region of Ghana.

\subsection{Lack of Logistics at the District Offices}

It was found that District Directors of Education of Gushegu Karaga, Saboba, and Tolon Kumbungu lack adequate logistics in their District Offices and this makes the data preservation very difficult. This observation was confirmed when one of the directors said that they do not have the needed computers and the needed experts to handle the data in their offices. He added that he has the data, how to preserve it in the offices is a big problem. There are no experts to handle the data and that is why we lose some relevant information in the offices. It was observed that in all the districts visited one could count only two computers; one in the District Director's Office with a printer and one computer in the General Office without a printer. The directors explained that they have been complaining to the government but no attention had been paid to their plea.

\section{Conclusion and Recommendations}

The underlying differences between government and NGO beliefs generate actions which define their interactions, government and NGOs must collaborate and cooperate to achieve productive outcomes in basic education in the region. These partners more or less have not collaborated effectively in spite of some success achieved by the NGOs in the region as explained above. The NGOs have not been able to find a solution to gender access gap in the region especially, in enrolment and attendance which existed for decades therefore; there is the need for attitudinal change on the part of both the NGOs and GES.

The NGOs often limit their role purposely to avoid tangling with the government. In other situations governments and NGOs hold negative perceptions of the other's capacity in supplying basic education and this often leads to a carefully defined and limited division of labor among NGOs and governments. Also the interactions between government and NGOs in the region have emerged from suspicion and frustration about one another's motivation which seem to be the most effective means for building a collaborative and interactive relationship. In this case also attitudinal change will be a motivation factor. There is the need for governments and NGOs to collaborate better to achieve results that are complimentary, the focus on increased learning about one another programme of activity in the region can help the NGOs address the gender access gap in enrolment and attendance for example when the NGOs in Ethiopia increase their exposure with the government education authorities, the school authorities cooperated effectively with them and they are able to eliminate disparity gaps in all areas where NGOs operated in Ethiopia.

A regional plan providing a framework for a comprehensive programme on basic education in the region should be developed by government. This framework should make room for the involvement of the NGOs working in the collaboration towards eliminating disparity in enrolment and attendance in the region. As part of the framework, an annual workshop of the 
NGOs and the Girl Child Education Unit should be encouraged for harmonization of figures relevant to enrolment and attendance of the girl child, the challenges as well as recommendations on the way forward.

Lastly, the NGOs with the support of the GES should initiate quarterly programme whereby sensitization on the effects of gender gaps in enrolment and attendance are done by educated men and women who hail from the various communities or who are natives of the communities. When this is done successfully parents and the girls will see their own brothers and sisters encouraging them to enrol the girls and allow them to attend school. The intervention by NGOs in basic education in the Northern Region is bedeviled with many challenges as explained in the paper and this explain many reasons why NGOs in the Northern Region have not been able to address the problem of gender disparity gap in school enrolment and attendance.

\section{References}

Abdulai, A. (2007). Putting Smiles on Pupil's Faces? An Assessment of the Food-For-Education Programme in West Mamprusi District Northern Ghana. Legon Journal of Sociology, 3(2), 24-44.

Action Aid (2004). Shepherd School Update Report. Accra, Ghana

Action Aid Ghana (2002). Ghana Pilot Education Survey: Draft Report. Accra, Ghana.

Action Aid, (2004). The Pastoralist Communities and Free Primary Education in Kenya: A preliminary survey Report. Nairobi, Kenya.

Alhassan, E. (2010). Socio Economic and Cultural Determinants of Girl Child Education in Gushegu/Karaga District of the Northern Region. Ghana Journal for Development Studies, 7(1), 50-72. http://dx.doi.org/10.4314/gjds.v7i1.61400

CARE (2005). Basic Education and Civil Society: (BECS) Project report on youth development initiative. Accra, Ghana: CARE International.

GES (2010). The Challenges of Gender and Education in Northern Ghana. Accra. Ghana: Ministry of Education.

GES (2011). Publication on Girls’ Education: Girls’ Education Unit of GES. Vol. 4. Accra, Ghana: Ministry of Education.

Ghana Statistical Service (2012). Ghana Population Census Accra. Ghana: Ghana Statistical Service.

Government of Ghana (2010). Ghana Millennium Development Goals Report. Accra Ghana: Ministry of Education.

Kouakou, D. (2011) The role of international NGOs in education: A case study of the Catholic Relief Service (CRS) IN Bunkpurugu Yuunyoo district of the Northern Region. Legon 
Journal of Sociology, 4(2), 97-122.

MOE (2010). Education Sector Review (ESR) Accra, Ghana: Ministry of Education.

Plan International (2000). Education for All: Rhetoric and Reality-an Independent analysis by Plan International.UK: Plan International Headquarters.

School for Life (2008). Report from Educational Forum of School for Life Held on the $19^{\text {th }}$ April 2001 at GNAT Hall, Tamale, Ghana.

Sen, A. (2007). Capability Approach and Social Justice in Education. New York USA: Palgrave Macmillan.

Tonah, S. (2011). The State of NGOs and Local Communities in the Provision of Basic Education. Legon Journal of Sociology, 4(2), 147-175.

Twumasi, P. A. (2001). Social Research in Rural Communities. Accra: Ghana Universities Press.

UNDP (2012). Report on Girl Child Accra, Ghana: UN Department of Information.

UNESCO (2004). The Bias behind Nomadic Education. Retrieved 10 September, 2011 from www.unesco.org

UNESCO (2011). Development of Education in Africa: A Statistical Review, Seventh Conference of Ministers of Education of African Member States between 20-24 ${ }^{\text {th }}$ April 1998. Durban, South Africa.

UNICEF (2001). The State of World Children New York, USA: UNICEF.

UNICEF (2012). the state of education of Children from Ghana's Rural and urban areas in Ghana. Accra, Ghana: UNICEF.

UNO (2006-2010). The Pilght of the Girl Child in Africa. Accra, Ghana: Ministry of Education.

UNO (2011). Ghana Education Report: Working paper 2010. Accra, Ghana: UNICEF

USAID (2006). Situational Analysis of Children and Women in Ghana. Accra: Accra Press.

Wood, M., \& Swam, M. (2001). Supply and Demand Factors Influencing the Educational Drop-Out Rate in Africa and Asia. Uganda: International Education Press.

World Bank (2004). A Chance to Learn: Knowledge and Finance of Education in Sub-Saharan Africa. Prepared for Distribution at a Conference for Education in 2000 April $26^{\text {th }}-28^{\text {th }}$ Daker, Senegal.

\section{Copyright Disclaimer}

Copyright reserved by the author(s).

This article is an open-access article distributed under the terms and conditions of the Creative Commons Attribution license (http://creativecommons.org/licenses/by/3.0/). 